\title{
THE IMPACT OF A CHIEF PLANNING OFFICER ON THE ADMINISTRATIVE ENVIRONMENT FOR PLANNING
}

\author{
Peter J. Hurst and Marvin W. Peterson
}

Institution-wide planning, to be effective, must have the support of key administrators. Presidents, vice-presidents, deans, and directors must feel that sufficient consensus can be reached on explicit goals to make comprehensive planning possible and worthwhile. While much has been written about the importance of CEO leadership in gaining broad support for planning, little has been said about the role of the chief planning officer in this regard. This paper, based on a national survey of administrators' views of planning, studies the relationship between having a chief planning officer and administrators' perceptions of campus planning. Its intended audience includes all those interested in institutional planning.

The post-World War II growth, leveling-off, and sporadic bursts of retrenchment in higher education in the United States have been paralleled by a growth of interest in institutional planning. This expanding interest is reflected in the increasing memberships of the two associations related to institutional planning and institutional research in higher education. The Society of College and University Planners (SCUP) has gone from a charter membership of 300 in 1966 to 2,820 members listed in the 1990-91 SCUP directory. The directory of the Association for Institutional Research (AIR), first published in 1966-67 with 392 names, lists 2,402 members in the 1990-91 AIR directory. While the number of planning officers in higher education institutions has continued to increase, the number of studies of their role in and impact on the planning process has not. How does the central coordination of the institutional planning function affect the planning process? Is the presence of a chief planning officer (CPO) related to differences in administrator perceptions of and attitudes to-

Peter J. Hurst, Office of Academic Planning and Analysis, University of Michigan, $520 \mathrm{E}$. Liberty St., Ann Arbor, MI 48109-2210. Marvin W. Peterson, Center for the Study of Higher and Postsecondary Education, University of Michigan.

Presented at the Thirty-first Annual Forum of the Association for Institutional Research, San Francisco, May 26-29, 1991. 
ward campus planning? This paper presents a data-based exploration of the latter question.

\section{LITERATURE}

Institutional planning has come to play a central role in the higher education management literature. Descriptions and analyses of planning processes include those of Cope $(1981,1985)$; Hollowood (1981); Keller (1983); Kotler and Murphy (1981); Parekh (1977); Peterson (1980); Scott (1986); Shirley (1988); and Steeples (1988). There is also a growing number of case studies of planning available including Chaffee (1983, 1984); Clugston (1986); Cope (1987); Farmer (1987); Hyatt (1984); Lelong and Hinman (1982); Poulton (1980); Schmidtlein and Milton (1990); Steeples (1988); Tack, Rentz, and Russell (1984); and Zemsky, Porter, and Oedel (1978). Although many authors have discussed the importance of executive leadership and the role of faculty participation, there is almost no mention or evaluation of the presence of an increasingly prevalent and central participant in the planning process--the chief planning officer. In addition, the literature that examines the role and function of university institutional research/planning offices and their leadership (e.g., Brown and Yeager, 1977; Miselis, 1988; Peterson and Corcoran, 1985; Storrar, 1981; Saupe, 1990) includes no studies of the utility of the CPO in the overall planning process.

\section{CONCEPTUAL FRAMEWORK}

Two important obstacles confront the study of CPOs. The first obstacle is the lack of homogeneity in title or job description of this position. The position may reside in any one of a number of functional areas of administration including: the president's office, finance or budget planning, academic affairs or academic planning, or institutional research. It may even be established as a separate function. Therefore, it is not surprising that titles for this position vary by institution as do reporting relationships and responsibilities. A second obstacle lies in the difficulty of isolating the impact of a CPO from other factors that influence institutional planning. These obstacles were removed in a recent national survey of institutional planning done by the National Center for Postsecondary Governance and Finance (NCPGF) under the direction of Dr. Frank Schmidtlein. The conceptual framework and the data for this study are drawn from the NCPGF research project. ${ }^{1}$

The dependent variables in this study, depicted in the conceptual framework in Figure 1, are (1) administrator perceptions of what current planning processes and values are on their campuses and (2) administrator attitudes about what planning processes and values should be. The framework for administra- 


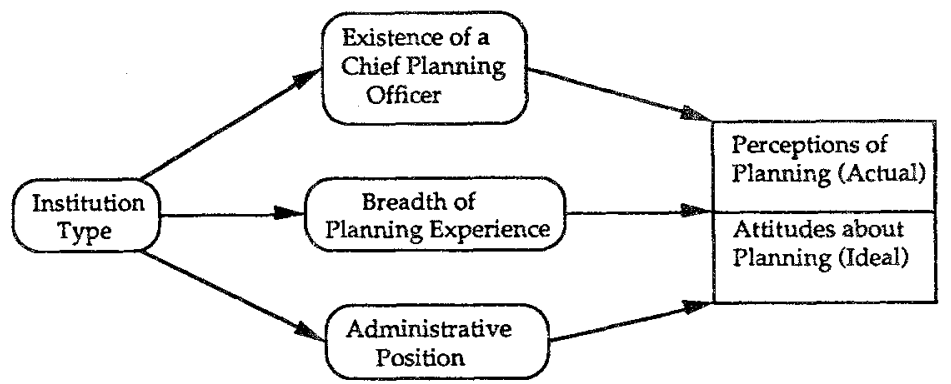

FIG. 1. Conceptual framework of the relationship between existence of a CPO and administrator perceptions of and attitudes about planning.

tors' perceptions and attitudes was constructed from Schmidtlein's (1973) plànning process paradigms, the "Comprehensive-Prescriptive" and the "Incremental-Remedial." The two paradigms were defined by Larson (1987, pp. 11-12) as follows:

Comprehensive-Prescriptive Planning is characterized by attention given to technical and analytical systems rather than to political or market processes. It is an approach in which means and ends are explicitly defined, are logically consistent, and cover a broad range of alternatives. This approach to planning usually entails formal analysis of costs and benefits and prescribes detailed goals and objectives that are often forecast into a long-range future (Churchman, 1983; Schultze, 1968).

Incremental-Remedial Planning is characterized by attention given to processes rather than to systems. It is an approach that usually focuses attention on the margins of the status quo, restricts consideration of the variety of alternatives and outcomes to a few, makes successive limited comparisons of means to ends, continually amends choices as trials require remediation, and fragments or pluralizes the decision process (Lindbloom and Braybrooke, 1965).

While the central relationship being examined is of the presence of a CPO to administrator perceptions of and attitudes about institutional planning, other variables have been included in this study. Administrator attitudes toward planning may vary by administrative position (Takeuchi, 1984). Also, the breadth of administrator involvement with past and present planning activities may have an impact on current perceptions of and attitudes toward planning. Therefore, these three variables (presence of a CPO, administrative position, and breadth of planning experience of the respondent) are considered here for their direct and interactive relationships with administrator perceptions and attitudes. Finally, the effect of institutional type is examined in this study as a contextual 
variable. If CPOs are overrepresented in any of the institutional types, then a relationship between CPO and administrator perceptions and attitudes may be due at least in part to institutional type. The conceptual framework of the four independent and twelve dependent variables is presented in Figure 1.

\section{RESEARCH QUESTIONS}

The central research question of this study was, "Do administrators who indicate the existence of a CPO have different perceptions of actual campus planning and attitudes about ideal campus planning than do administrators who indicate that there is not a CPO on their campus?" The following subquestions were developed to guide the analysis:

1. Is there a relationship between institutional type and the other three independent variables (existence of a CPO, administrative position, breadth of planning experience)?

2. Is there a relationship between institutional type and the dependent variables (administrator perception of and attitudes about planning)?

3. Are there relationships between the three independent variables and the dependent variables?

4. What is the relative impact of the existence of a $\mathrm{CPO}$, controlling for the other independent variables?

\section{DATA SOURCES AND METHODS}

The NCPGF study involved a survey of 3,333 college administrators at 256 higher education institutions. ${ }^{2}$ The institutions were randomly selected within two levels of stratification. The first level of stratification divided institutions by type-research university, state college, private liberal arts college, and community college. The second level subdivided each type by a set of major characteristics, for example, research universities into public and private, state colleges into unionized and not unionized, etc. Questionnaires were sent to administrators in 20 different positions at each institution and included trustees, CEOs, vice-presidents, deans, and directors. The overall response rate for the survey was 45.8 percent. The NCPGF study, while based on a stratified, random sample of institutions, was weighted toward larger institutions that tended to have more of the administrative positions that were being surveyed. For example, while research university and private college responses each represented 25 percent of the institutions surveyed, research universities alone accounted for 33.6 percent of the individual responses while liberal arts colleges accounted for only 18 percent. The authors of the study explained that the results were "not intended as definitive answers to planning questions but rather 
as stimulating suggestions for further qualitative study and evaluation" (Larson, 1987). Accordingly, the authors of this study wish to state the same caveat.

Data sources for the independent and dependent variables were:

1. Existence of a $\mathrm{CPO}$ - This variable is taken from a survey item worded as follows: "Does your institution have a senior administrative officer whose principal duty is to coordinate institution-wide planning?" ___ Yes No

Of the 1456 responses to this question, 841 answered "Yes" and 615 "No."

2. Administrative Position-A typology of administrative positions in the Higher Education Directory was used to identify the respondent's position. They were clustered into three position categories for this study:

(a) Executive Officers (CEO, chief academic officer, chief financial officer, chief student services officer, chief development officer, chief planning officer)

(b) Deans and Chairs

(c) Mid-level managers (registrar; head librarian; directors of admissions, counseling, financial aid, institutional research, computer center, and alumni relations)

3. Breadth of Planning Experience-One survey question asked, "Please check all of the planning activities listed below in which you have personally participated at any postsecondary education institution."

College-wide planning committee member

Evaluate and offer advice about a plan

Provide statistical or other technical analysis of a planning issue Review and approve a plan

Hold administrative responsibility for plan implementation

Draft a plan proposal

None of the above

The breadth of planning experience variable used in this study was a total of the number of activities participated in ranging from 0 to 6 , broken into three categories as follows:

(1) $0-2$ activities

(2) 3-4 activities

(3) 5-6 activities

4. Institutional Type-The four institutional categories represented in this study were:

(1) Research University

(2) Liberal Arts College 
(3) State College

(4) Community College

5. Administrator Perceptions of and Attitudes about Planning-Administrators were asked to respond on a nine-point scale to six planning process and values topics. The response scale varied for each topic spanning statements drawn from Schmidtlein's planning paradigms. The six topics and a shortened version of the statements are listed below:

1. Response to change:

(a) systematic and long-range vs. (b) incremental and short-range

2. Reducing risks and uncertainty:

(a) Quantitative analysis vs. (b) marginal adjustment

3. Defining goals:

(a) explicitly vs. (b) implicitly

4. Reaching consensus on priorities:

(a) by quantitative analysis of needs vs. (b) by bargaining and compromise

5. The main objective of planning:

(a) optimum choices vs. (b) satisfactory choices

6. The better approach to planning:

(a) comprehensive/prescriptive vs. (b) incremental/remedial

The nine-point scales connected the (a) and (b) positions so that, for example, a response of " 1 " on the scale for topic one indicated a systematic and long-range response to change (the C-P paradigm) while " 9 " indicated an incremental and short-range response to change (the I-R paradigm). For each of the six topics, respondents indicated what location on the nine-point interval scale best characterized their perception of actual institutional planning. On a second nine-point scale they indicated their attitude about how planning ideally should be done. The two scaled responses for each of the six items yielded twelve total responses: six planning perceptions and six planning attitudes. These comprised the dependent variables of the study.

At the core of the study is the strength of the relationship between having a CPO and administrator perceptions of and attitudes about planning. This relationship is studied relative to two other variables that may influence administrative perceptions of planning; administrative position and breadth of planning experience. These relationships are examined in the context of institutional type. If a relationship exists between institutional type and the other independent variables, institutional type must be controlled for in further analysis. If a relationship also exists between institutional type and the dependent variables, then the independent variables' relationships with the dependent variables must be considered in the context of institutional type. These considerations set the sequence of data analysis. 
TABLE 1. Distribution of CPOs, Breadth of Planning Experience, and Administrative Positions by Institutional Type

\begin{tabular}{|c|c|c|c|c|c|}
\hline \multirow[b]{2}{*}{$\mathrm{CPO}$} & \multicolumn{4}{|c|}{ Chief Planning Officer } & \multirow[b]{2}{*}{ Totals } \\
\hline & $\begin{array}{l}\text { Research } \\
\text { University }\end{array}$ & $\begin{array}{l}\text { Liberal Arts } \\
\text { College }\end{array}$ & $\begin{array}{c}\text { State } \\
\text { College }\end{array}$ & $\begin{array}{c}\text { Community } \\
\text { College }\end{array}$ & \\
\hline \multirow[t]{2}{*}{ 1. CPO-yes } & 278 & 133 & 221 & 209 & 841 \\
\hline & $57 \%$ & $51 \%$ & $55 \%$ & $69 \%$ & $58 \%$ \\
\hline \multirow[t]{2}{*}{ 2. CPO-no } & 212 & 129 & 178 & 96 & 614 \\
\hline & $43 \%$ & $49 \%$ & $45 \%$ & $32 \%$ & $42 \%$ \\
\hline Totals & 490 & 262 & 399 & 305 & 1456 \\
\hline \multirow[t]{3}{*}{ Chi Sq Sig $=.000$} & $34 \%$ & $18 \%$ & $27 \%$ & $21 \%$ & $100 \%$ \\
\hline & \multicolumn{4}{|c|}{ Breadth of Planning Experience } & \\
\hline & $\begin{array}{l}\text { Research } \\
\text { University }\end{array}$ & $\begin{array}{c}\text { Liberal Arts } \\
\text { College }\end{array}$ & $\begin{array}{c}\text { State } \\
\text { College }\end{array}$ & $\begin{array}{l}\text { Community } \\
\text { College }\end{array}$ & Totals \\
\hline \multirow[t]{2}{*}{ 1. $0-2$} & 87 & 70 & 89 & 54 & 300 \\
\hline & $17 \%$ & $26 \%$ & $22 \%$ & $18 \%$ & $20 \%$ \\
\hline \multirow[t]{2}{*}{ 2. $3-4$} & 149 & 89 & 134 & 88 & 460 \\
\hline & $30 \%$ & $33 \%$ & $33 \%$ & $29 \%$ & $31 \%$ \\
\hline \multirow[t]{2}{*}{ 3. $5-6$} & 267 & 114 & 183 & 166 & 730 \\
\hline & $53 \%$ & $42 \%$ & $45 \%$ & $54 \%$ & $49 \%$ \\
\hline Totals & 503 & 273 & 406 & 308 & 1490 \\
\hline \multirow[t]{2}{*}{ Chi Sq Sig $=.007$} & $34 \%$ & $18 \%$ & $27 \%$ & $21 \%$ & $100 \%$ \\
\hline & $\begin{array}{l}\text { Research } \\
\text { University }\end{array}$ & $\begin{array}{l}\text { Administrati } \\
\text { Liberal Arts } \\
\text { College }\end{array}$ & $\begin{array}{l}\text { Position } \\
\text { State } \\
\text { College }\end{array}$ & $\begin{array}{c}\text { Community } \\
\text { College }\end{array}$ & Totals \\
\hline \multirow[t]{2}{*}{ 1. Executive Officers } & 146 & 123 & 156 & 140 & 565 \\
\hline & $30 \%$ & $46 \%$ & $38 \%$ & $46 \%$ & $38 \%$ \\
\hline \multirow[t]{2}{*}{ 2. Deans } & 150 & 11 & 95 & 43 & 299 \\
\hline & $34 \%$ & $4 \%$ & $24 \%$ & $12 \%$ & $20 \%$ \\
\hline \multirow[t]{2}{*}{ 3. Directors } & 198 & 133 & 158 & 120 & 609 \\
\hline & $40 \%$ & $50 \%$ & $39 \%$ & $40 \%$ & $41 \%$ \\
\hline Totals & 494 & 267 & 409 & 323 & 1473 \\
\hline Chi Sq Sig $=.000$ & $34 \%$ & $18 \%$ & $28 \%$ & $22 \%$ & $100 \%$ \\
\hline
\end{tabular}

\section{ANALYTIC RESULTS}

1. Existence of a CPO, Breadth of Planning Experience, and Administrative Position by Institutional Type-Since three of the four variables are categorical, contingency table analysis was used. The data and the resulting chi-square analyses are presented in Table 1 . There were signigicant differences in the 
TABLE 2. Administrator Perceptions and Attitudes About Institutional Planning by Institutional Type (One-way anova and Comparisons of Means)

\begin{tabular}{|c|c|c|c|c|c|c|}
\hline Perceptions and & Sig. of F. & & titutional Type & Mean Sc & & P. $<.05$ for \\
\hline PERCEPTIONS: & & $\begin{array}{l}\text { Research } \\
\text { University }\end{array}$ & $\begin{array}{l}\text { Liberal Arts } \\
\text { College }\end{array}$ & $\begin{array}{l}\text { State } \\
\text { College }\end{array}$ & $\begin{array}{c}\text { Community } \\
\text { College }\end{array}$ & \\
\hline $\begin{array}{l}\text { 1. Response to } \\
\text { Change } \\
\text { 2. Reducing } \\
\text { Risks and } \\
\text { Uncertainty } \\
\text { 3. Defining } \\
\text { Goals } \\
\text { 4. Reaching } \\
\text { Consensus } \\
\text { 5. Main } \\
\text { Objective of } \\
\text { Planning } \\
\text { 6. Better } \\
\text { Approach to } \\
\text { Planning } \\
\end{array}$ & .000 & 5.624 & 5.011 & 5.281 & 5.172 & RU - LA \\
\hline ATTITUDES: & & & & & & \\
\hline $\begin{array}{l}\text { 1. Response to } \\
\text { Change } \\
\text { 2. Reducing } \\
\text { Risks and } \\
\text { Uncertainty }\end{array}$ & .002 & 4.069 & 3.713 & 4.033 & 4.380 & LA - CC \\
\hline $\begin{array}{l}\text { 3. Defining } \\
\text { Goals }\end{array}$ & & & & & & \\
\hline $\begin{array}{l}\text { 4. Reaching } \\
\text { Consensus }\end{array}$ & .001 & 4.538 & 4.049 & 4.053 & 4.325 & $\begin{array}{l}\text { RU - LA } \\
\text { RU - SU }\end{array}$ \\
\hline $\begin{array}{l}\text { 5. Main } \\
\text { Objective of } \\
\text { Planning }\end{array}$ & .015 & 4.676 & 4.242 & 4.215 & 4.384 & $\mathrm{RU}-\mathrm{SU}$ \\
\hline $\begin{array}{l}\text { 6. Better } \\
\text { Approach to } \\
\text { Planning }\end{array}$ & .000 & 3.966 & 3.532 & 3.669 & 4.208 & $\begin{array}{l}\text { RU - LA } \\
L A-C C \\
S U-C C\end{array}$ \\
\hline
\end{tabular}

distribution of all three of the independent variables by the contextual variable, institutional type. The ratio of respondents who indicated the presence of a CPO to those who indicated that there was not a CPO was much higher in community college respondents than respondents from the other institutional types. The breadth of planning experience was less in liberal arts colleges and state colleges than the other two types. Finally, administrative position categories were not evenly distributed across institutions. Liberal arts colleges and 
community colleges tend not to use dean titles to the extent that they are used by universities. The relationships between institutional type and the other independent variables dictate that institutional type must be controlled for when the relationships of these variables with the dependent variables are tested.

2. Administrator Perceptions and Attitudes by Institutional Type-A oneway analysis of variance was used to look for significant difference in administrator perception and attitude mean scores among the four institutional types. The results are presented in Table 2 . Institutional type was related to only one of the six administrator perceptions of current institutional planning processes, how consensus is achieved (perception item \#4). Research university administrator perceptions of how consensus is achieved were significantly closer to the bargaining and compromise end of the response scale than the perceptions of liberal arts college administrators. Administrator attitudes about how planning should ideally be done were related to institutional type for four of the six topics. The responses from liberal arts colleges and state colleges tended to be closer to the Comprehensive/Prescriptive model. The relationship between institutional type and the dependent variables necessitated that it be considered in evaluating the relative strength of relationship of the three other independent variables with the dependent variables.

3a. Effect of the Existence of a CPO on Administrator Perceptions and Attitudes by Institutional Type - Having established the relationships between institutional type and both the other independent variables and the dependent variables, the analysis of the relationship between the existence of a CPO and administrator perceptions and attitudes, proceeded controlling for institutional type. Forty-eight T-tests were used to test the significance of differences between the group means of CPO-yes and CPO-no on the twelve perception and attitude variables for the four institutional types. The results are presented in Table 3. The relationship between the existence of a CPO and administrator perceptions of campus planning is striking. On all six of the perception variables, across all four institutional types, mean responses for CPO-yes were lower (closer to the Comprehensive/Prescriptive model) than were the mean responses for CPO-no. The differences were significant for 22 of the 24 tests (six perception variables by four institutional types).

A relationship also exists between the existence of a CPO and administrator attitudes about how planning should ideally be done. The CPO-yes group mean scores were lower than the CPO-no group mean scores for 22 of the 24 administrator attitude T-tests. Twelve of the 24 differences between means were significant. Community college administrator attitudes toward planning were not significantly related to the existence of a CPO.

3b. Effect of Breadth of Planning Experience on Administrator Perceptions and Attitudes by Institutional Type-The next step of the analysis was to test the relationship of the second independent variable, breadth of planning experi- 


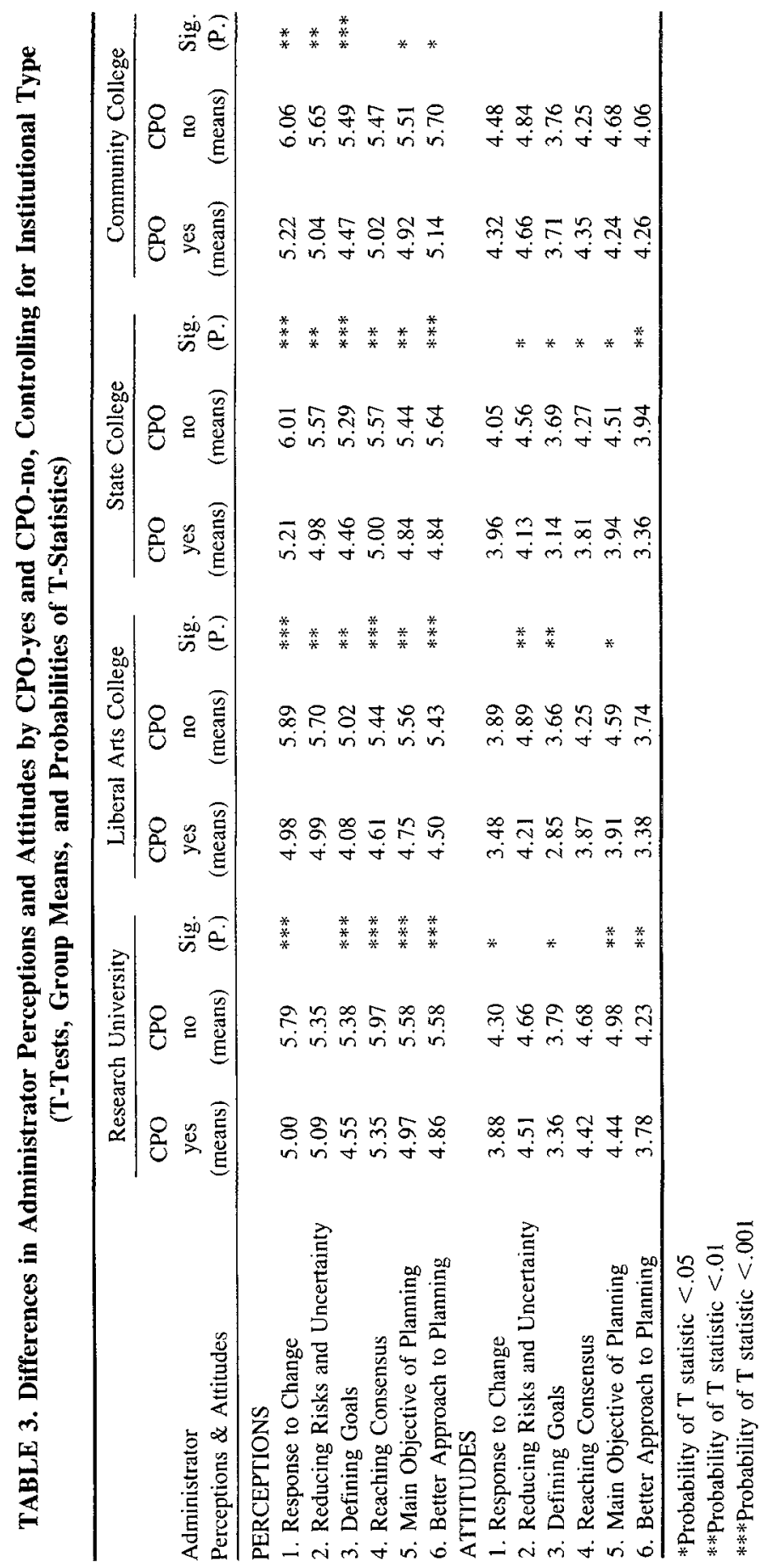


TABLE 4. Administrator Perceptions and Attitudes by Breadth of Planning Experience, Controlling for Inst. Type (One-way ANova and Comparisons of Means)

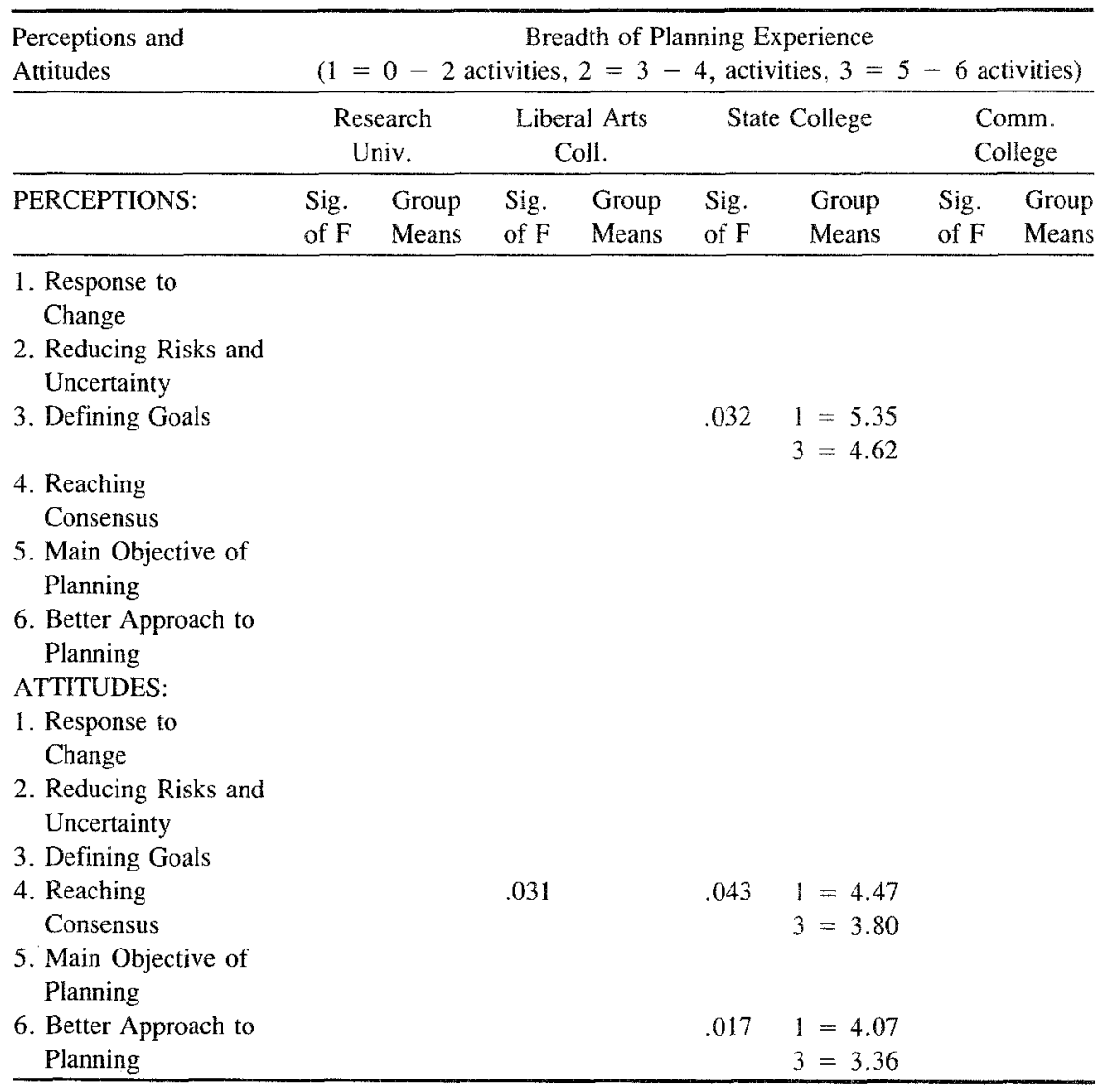

ence, with the dependent variables, perception of and attitude toward planning A one-way analysis of variance of breadth of planning experience mean scores for the dependent variables was run for each institutional type. With the exception of some differences by experience for state college respondents, little relationship was found between breadth of planning experience and administrator perceptions of and attitudes toward institutional planning. The results are presented in Table 4.

3c. Effect of Administrative Position on Administrator Perceptions and Attitudes by Institutional Type-The final step in this stage of the analysis examined the relationship between administrative position and administrator perceptions and attitudes toward planning, controlling for institutional type. A 
TABLE 5. Administrator Perceptions and Attitudes by Administrative Position, Controlling for Institutional Type (One-way ANova and Comparisons of Means)

\begin{tabular}{|c|c|c|c|c|c|c|c|c|}
\hline \multirow{3}{*}{$\begin{array}{l}\text { Perceptions and } \\
\text { Attitudes } \\
\text { PERCEPTIONS: }\end{array}$} & \multicolumn{8}{|c|}{$\begin{array}{c}\text { Administrative Position } \\
(1=\text { Executive Officers, } 2=\text { Deans, } 3=\text { Directors })\end{array}$} \\
\hline & \multicolumn{2}{|c|}{$\begin{array}{l}\text { Research } \\
\text { University }\end{array}$} & \multicolumn{2}{|c|}{$\begin{array}{l}\text { Liberal Arts } \\
\text { College }\end{array}$} & \multicolumn{2}{|c|}{ State College } & \multicolumn{2}{|c|}{$\begin{array}{c}\text { Community } \\
\text { College }\end{array}$} \\
\hline & $\begin{array}{l}\text { Sig. } \\
\text { of } F\end{array}$ & $\begin{array}{l}\text { Group } \\
\text { Means }\end{array}$ & $\begin{array}{l}\text { Sig. } \\
\text { of } F\end{array}$ & $\begin{array}{l}\text { Group } \\
\text { Means }\end{array}$ & $\begin{array}{l}\text { Sig. } \\
\text { of } F\end{array}$ & $\begin{array}{l}\text { Group } \\
\text { Means }\end{array}$ & $\begin{array}{l}\text { Sig. } \\
\text { of } F\end{array}$ & $\begin{array}{l}\text { Group } \\
\text { Means }\end{array}$ \\
\hline $\begin{array}{l}\text { 1. Response to } \\
\text { Change } \\
\text { 2. Reducing } \\
\text { Risks and } \\
\text { Uncertainty }\end{array}$ & & & & & & & & \\
\hline $\begin{array}{l}\text { 3. Defining } \\
\text { Goals } \\
\text { 4. Reaching } \\
\text { Consensus } \\
\text { 5. Main } \\
\text { Objective of } \\
\text { Planning }\end{array}$ & .029 & $\begin{array}{l}1=4.60 \\
3=5.24\end{array}$ & & & .043 & & & \\
\hline $\begin{array}{l}\text { 6. Better } \\
\text { Approach to } \\
\text { Planning }\end{array}$ & & & & & & & & \\
\hline $\begin{array}{l}\text { ATTITUDES: } \\
\text { 1. Response to } \\
\text { Change }\end{array}$ & .000 & $\begin{array}{l}1=4.53 \\
2=4.18 \\
3=3.66\end{array}$ & & & & & & \\
\hline $\begin{array}{l}\text { 2. Reducing } \\
\text { Risks and } \\
\text { Uncertainty }\end{array}$ & .006 & $\begin{array}{l}1=4.91 \\
3=4.26\end{array}$ & & & & & & \\
\hline $\begin{array}{l}\text { 3. Defining } \\
\text { Goals } \\
\text { 4. Reaching } \\
\text { Consensus }\end{array}$ & & & & & & & & \\
\hline $\begin{array}{l}\text { 5. Main } \\
\text { Objective of } \\
\text { Planning }\end{array}$ & & & & & & & & \\
\hline $\begin{array}{l}\text { 6. Better } \\
\text { Approach to } \\
\text { Planning }\end{array}$ & & & & & & & & \\
\hline
\end{tabular}

one-way analysis of variance of the effect of administrative position on each of the dependent variables was run for each institutional type. Although some differences by administrative position were found for research universities, in general, little relationship existed between these variables. The results are displayed in Table 5. 
TABLE 6. Administrator Perceptions and Attitudes by CPO Institutional Type, Administrative Position, Breadth of Planning Experience, and Interactions

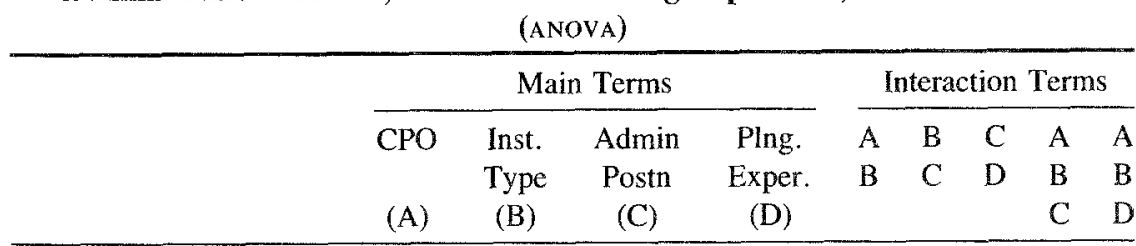

\section{PERCEPTIONS:}

1. Response to Change

2. Reducing Risks and Uncertainty

3. Defining Goals

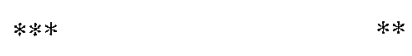

4. Reaching Consensus

**** $* * ;$

5. Main Objective of Planning

6. Better Approach to Planning

ATTITUDES:

1. Response to Change

2. Reducing Risks and Uncertainty

3. Defining Goals

4. Reaching Consensus

5. Main Objective of Planning

6. Better Approach to Planning

* Probability of $\mathrm{F}$ statistic $<.05$

$*$ Probability of $F$ statistic $<.01$

$* * *$ Probability of F statistic $<.001$

4. Effect of the Existence of a CPO on Administrator Perceptions and Attitudes Controlling for All Other Variables-The final analysis was a four-way ANOVA. The relationships of each of the three independent variables and of institutional type with the dependent variables were considered simultaneously. The resulting analysis is displayed as Table 6 .

When all four variables were considered simultaneously (institutional type, administrative position, breadth of planning experience, and the existence of a CPO), the existence of a CPO made the most significant difference in administrator perceptions of how planning was actually being carried out. As was shown earlier (Table 3), the difference favored the Comprehensive/Prescriptive paradigm. Breadth of planning experience was related to administrator percep- 
tion of explicitness of goal definition (item \#3) and institutional type was related to administrator perceptions of how consensus is achieved (item \#4).

While the presence of a CPO also has a clear relationship with most of the administrator attitude variables, it does not stand out relative to the other independent variables to the same extent as it did for the perception variables. Table 6 suggests that both the existence of a CPO and institutional type have strong independent relationships with most of the administrator attitude variables. Various interaction terms also have significant independent relationships with some of the attitude variables.

\section{DISCUSSION AND CONCLUSIONS}

The results of this study that used a broad sample of administrators from diverse institutions surveyed in the NCPGF project suggest a relationship between the presence of a CPO and administrators' perceptions of and attitudes about institutional planning. In all four institutional types, the presence of a $\mathrm{CPO}$ was accompanied by an increase in the perception of more comprehensive and rational processes of campus planning. The presence of a CPO also seemed to increase the likelihood that administrators' attitudes about ideal planning would favor comprehensive processes to a greater extent than administrators who reported no CPO position on their campus. Most importantly, the presence of a CPO had a greater effect on perceptions of how planning was handled on campus than did institutional type or administrative position or breadth of planning experience of the respondent.

The generalizability of these findings is limited by the fact that the unit of analysis was the individual administrator and not the individual campus. For example, in examining responses by institution, we were surprised to discover a lack of agreement among administrators about the presence of a CPO. We found that agreement about whether or not there was a senior administrative officer whose duty it is to coordinate institution-wide planning existed in only 57 percent of the institutions ( 82 of 143 ). ${ }^{3}$ Even in surveyed institutions that had listed a chief planning officer in the Higher Education Directory $(n=47)$ and who had enough respondents to make the test of agreement meaningful ( $n=32$ ), only 63 percent $(n=20$ ) agreed that there actually was such a person in the institution. The lack of agreement suggested by these two attempts to verify the survey responses is striking and suggests the results need to be viewed tentatively.

However, the emphasis of these findings on the perceptions of the individual administrator is still important. Despite the limited agreement within an institutions as to whether a CPO position exists, those administrators who think that there is a CPO are more likely to perceive the planning process as systematic, comprehensive, and rational than are their colleagues who say that there is no 
CPO. How might these findings be interpreted? The simplest, broadest interpretation is that CPOs actually do make institution-wide planning processes more comprehensive, systematic, explicit, etc. This interpretation is bolstered by the likelihood that administrators take the staffing of the CPO position as an institutional commitment to a comprehensive, analytical planning process. Thus, the CPO to some extent may symbolize the rationality of the process, thereby bringing it legitimacy and credibility.

A more mundane explanation is also possible. The presence of a CPO may indicate that a particular campus is currently involved in a visible planning process. If that were the case, it would be likely that planning on that campus at that time would look more systematic and comprehensive than its status quo, the incremental alternative. Unfortunately, the NCPGF survey did not include a question asking if there was currently a formal, institution-wide planning process in place, so it is not possible to test this hypothesis.

\section{NOTES}

1. Institutional Planning Project of the National Center for Postsecondary Governance and Finance, funded by a grant from the Office of Research, U.S. Department of Education. The authors wish to express their gratitude to Frank Schmidtlein, Toby Milton, and Jon Larson for providing access to the data from their study.

2. The survey instrument, methodology, and results are presented in Larson (1987).

3. Institutions were included in this analysis if they were represented by three or more respondents from a group consisting of executive officers, deans, and directors of institutional research. Agreement was defined as at least 70 percent consensus among the respondents.

\section{REFERENCES}

Brown, M. K., and Yeager, J. L. (1977). The impact of planning systems on managing and staffing an institutional research office. Paper presented at the Forum of the Association for Institutional Research, Montreal.

Chaffee, E. E. (1983). The role of rationality in university budgeting. Research in Higher Education 19(4): 387-406.

Chaffee, E. E. (1984). Successful strategic management in small private colleges. Journal of Higher Education 55(2): 212-241.

Churchman, C. W. (1968). The Systems Approach. New York: Dell.

Churchman, C. W. (1983). The Systems Approach. New York: Dell.

Clugston, R. M., Jr. (1986). Strategic planning in an organized anarchy: The emperor's new clothes? Paper presented at the Annual Meeting of the Association for the Study of Higher Education. San Antonio, TX: ED 268902

Cope, R. G. (1981). Strategic Planning, Management, and Decision Making. AAHEERIC Higher Education Reports 9. Washington, DC: American Association for Higher Education.

Cope, R. G. (1985). A contextual model to encompass the strategic planning concept: Introducing a newer paradigm. Planning for Higher Education 13(3): 13-20.

Cope, R. G. (1987). Opportunity from Strength: Strategic Planning Clarified with Case Examples. ASHE-ERIC Higher Education Reports 8. Washington, DC: Association for the Study of Higher Education. 
Farmer, D. W. (1987). Taking charge of change through matrix management. Planning for Higher Education 15(2): 18-29.

Hollowood, J. R. (1981). College and university strategic planning: A methodological approach. Planning for Higher Education 9(4): 8-18.

Hyatt, J. (1984), Reallocation: Strategies for Effective Resource Management. National Association of College and University Business Officers.

Keller, G. (1983). Academic Strategy. Baltimore: Johns Hopkins University Press.

Kotler, P. R., and Murphy, Patrick (1981). Strategic planning for higher education. Journal of Higher Education 52(5): 470-489.

Larson, J. (1987). Senior administrator attitudes about planning. Paper presented at the annual meeting of the Association for the Study of Higher Education. Baltimore: ED 292390.

Lelong, D. C., and Hinman, Martha M. (1982). Implementation of Formal Planning (Publications in Higher Education 15). Ann Arbor: Center for the Study of Higher Education, University of Michigan.

Lindbloom, C. E., and Braybrooke, D. (1965). The Intelligence of Democracy: Decision Making Through Mutual Adjustment. New York: The Free Press.

Miselis, K. L. (1988). The organizational relationship between planning/institutional research and administrative information systems in higher education. Paper presented at the Forum of the Association for Institutional Research. Phoenix: ED 298849.

Parekh, S. (1977). Long Range Planning. New York: Change Magazine Press.

Peterson, M. W. (1980). Analyzing alternative approaches to planning. In Paul Jedamus and Marvin Peterson (eds.), Improving Academic Management (pp, 113-163). San Francisco: Jossey-Bass.

Peterson, M. W., and Corcoran, M. (eds.) (1985). Institutional Research in Transition. New Directions in Institutional Research 46. San Francisco: Jossey-Bass.

Poulton, N. L. (1980). Impacts of planning activities in research universities: A comparative analysis of five institutional experiences. Unpublished doctoral dissertation, University of Michigan, Ann Arbor.

Saupe, J. L. (1990). The Functions of Institutional Research, 2nd edition. Tallahassee: The Association for Institutional Research.

Schmidtlein, F. A. (1973). The selection of decision process paradigms in higher education: Can we make the right decisions or must we make the decision right? Ford Foundation Program for Research in University Administration (P-42). Berkeley: University of California.

Schmidtlein, F. A., and Milton, T. H. (eds.) (1990). Adapting Strategic Planning to Campus Realities. New Directions for Institutional Research 67. San Francisco: Jossey-Bass.

Schultze, C. E. (1968). The Politics and Economics of Public Spending. Washington, DC: The Brookings Institution.

Scott, C. L. (1986). Launching successful planning efforts. Planning for Higher Education 14(2): 26-29.

Shirley, R. C. (1988). Strategic planning: An overview. In D. W. Steeples (ed.), Successful Strategic Planning: Case Studies. New Directions for Institutional Research 64. San Francisco: Jossey-Bass.

Steeples, D. W. (1988). Concluding observations. In D. W. Steeples (ed.), Successful Strategic Planning: Case Studies. New Directions for Higher Education 64. San Francisco: Jossey-Bass.

Storrar, S. J. (1981). Perceptions of organizational and political environments: Results of a national survey of institutional research/planning officers at large public univer- 
sities. Paper presented at the Forum of the Association for Institutional Research. Minneapolis/St. Paul.

Tack, M. W., Rentz, A. M., and Russell, Ronald L. (1984). Strategic planning for academic programs: A strategy for institutional survival. Planning for Higher Education 12(4): 8-14.

Takeuchi, S. M. (1984). Planning support for the top: An application of "Miles' Law" (Where you stand depends on where you sit). Planning for Higher Education 12(2): $1-5$.

Zemsky, R. W., Porter, R., and Oedel, L. P. (1978). Decentralized planning: To share responsibility. Educational Record 59(3): 229-253. 